\title{
Proroctwo życia osób konsekrowanych: „być domem” odkupionych relacji ewangelicznych
}

Temat, który mam przedstawić, zrodził się z intensywnego zainteresowania pytaniem o tożsamość życia konsekrowanego, a zarazem z odpowiedzi, jaką sugeruje nam obecny papież Franciszek. Zainteresowanie to narastało we mnie w miarę prowadzenia wykładów o biblijnych podstawach konsekracji zakonnej. Prędzej czy później należało dotrzeć do najgłębszej (i najnowszej) teologicznej refleksji na temat specyfiki daru skierowanego do tych, którzy podejmują drogę rad ewangelicznych. Jest to, jak widać, pewien proces, któremu podlegamy wszyscy, wędrując razem z Kościołem i odczytując wraz z nim coraz głębiej istotę Mystici Corporis Christi - Mistycznego Ciała Chrystusa, w którym szczególną rolę odgrywają od zawsze osoby konsekrowane. Jak wskazuje hasło roku poświęconego życiu konsekrowanemu: „Evangelium - Prophetia - Spes” (Ewangelia, Proroctwo, Nadzieja), proroczy wymiar drogi wedlug rad ewangelicznych jest jednym z najistotniejszych elementów tego daru.

\section{Czy mamy tu jakiś problem?}

Najczęściej proponowaną odpowiedzią na pytanie o specyfikę życia konsekrowanego na drodze rad ewangelicznych był do tej pory 
„radykalizm”. To właśnie owo najgłębiej „zakorzenione” (łac. radix - korzeń) podejście do wzywającego Pana miałoby być cechą wyróżniającą konsekrowanych spośród innych ochrzczonych, sugerując czasem ich większą doskonałość. Z czasem doskonałość zaczęła być rozumiana jako doskonałość miłości (,,perfecta caritas”). We wszystkim innym, a czasem nawet w tym, co specyficznie nasze, ,nie jesteśmy lepsi” (kard. João Braz de Aviz, wypowiedź w Pattaya, 2015)․․ Istotnie, pokutująca jeszcze czasem teza o stanie wyższej doskonałości bez stosownych kwantyfikatorów natychmiast rodzi trudności, budząc stare demony: dzielenie chrześcijan na stany życia doskonalszego, z dominantą Ducha, i na stany życia poniekąd zbrukanego materią, z dominantą minimalistycznego zachowywania 10 przykazań.

Zanim przyszedł papież Franciszek, jedna z ostatnich hipotez ustawiała sprawę dość ciekawie: osoby konsekrowane niosą w sobie radykalne podejście do... radykalizmu, wspólnego wszystkim ochrzczonym. Byłby to zatem superradykalizm, radykalizm do kwadratu albo - mówiąc językiem mediów - „Radykalizm wersja 2.0” (cokolwiek mialoby to oznaczać). Konsekrowani mieliby otrzymać w darze poniekąd większą heroiczność w braniu wezwań Ewangelii na serio. Ich służba polegałaby na gwarantowaniu „,zasobów” radykalizmu dla wszystkich wierzących, którzy mogliby się nimi zainspirować i naśladować ich w swego rodzaju całościowym podejściu do nowości życia w Chrystusie.

Wraz z papieżem Franciszkiem nastąpiło uproszczenie tej kwestii. Konsekrowani - zdaniem Franciszka - nie wyróżniają się w swoim powołaniu radykalizmem, który jest cechą wszystkich uczniów Chrystusa, lecz właśnie proroctwem. Innymi słowy, jeśli istnieją pośród nas wierzący, którzy posiadają dar i funkcję bycia prorokami, to w pierwszym rzędzie byliby to właśnie konsekrowani. Do nich kieruje swój apel papież Bergoglio: „obudźcie świat!”2

1 Sympozjum La vita consacrata al servizio della nuova evangelizzazione (20-24.07.2015), Pattaya, Tajlandia. „Non siamo meglio di altri nella Chiesa, e il radicalismo evangelico non è un'esclusiva della vita consacrata, ma appartiene a tutti, perché non esistono cristiani di serie A e cristiani di serie B". Questo riguarda anche i rapporti tra gli stessi religiosi che - ha detto - devono vivere „come fratelli e sorelle e non come superiori e subalterni”, http://it.radiovaticana. va/news/2015/07/24/card_braz_de_aviz_a_religiosi_asiatici_cristo_al_centro/1160471_(24.07 2015, strona włoska Radia Watykańskiego).

2 W dniach 15-19 września 2015 r. w Rzymie odbyło się jedno z najbardziej znaczących wydarzeń w Roku Życia Konsekrowanego. Były to światowe warsztaty dla młodych osób konsekrowanych, przebiegające pod hasłem: 
Profetyzm byłby pierwszym szczególnym znamieniem osób, które przyjmują rady ewangeliczne i pozwalają się konsekrować samemu Ojcu, by mocą Ducha Świętego kontynuować jako „żywa pamiątka” dzieło Jezusa w świecie i reprezentować jego Osobę. Nic więc dziwnego, że hasło roku życia zakonnego w Kościele brzmi: „Evangelium, Prophetia, Spes. Vita consecrata in Ecclesia hodie".

Mimo to jeszcze przed apelem papieża „Obudźcie świat!” nie brakowało głosów krytycznych na temat zbyt szybkiego „,zawłaszczania” charyzmatu prorockiego przez osoby zakonne. Nie mówiąc już o problemach pojmowania tego wymiaru po prostu ,nominalnie”: zakonnicy i zakonnice zawsze są prorokami, już przez sam swój stan, niemal instytucjonalnie, poniekąd bez względu na jakość dawanego świadectwa... Jak w kwestii radykalizmu, tak i tu przecież musimy przynajmniej wspomnieć niezaprzeczalny fakt, że w chrzcie świętym wszyscy zostajemy wszczepieni w Osobę Jezusa: Króla, Pasterza i Proroka.

Urząd prorocki Jezusa z Nazaretu staje się udziałem i odpowiedzialnością każdego ochrzczonego. Przed nami zatem niebagatelne zadanie: musimy wsłuchać się dobrze we wskazania Następcy św. Piotra, by dobrze uchwycić jego interpretację specificum życia konsekrowanego w Kościele i świecie, by żyć w radości i wolności i promieniować tym pośród ludzi.

\section{Prowokacje papieża Franciszka}

Wszyscy chrześcijanie są wezwani do życia według Ewangelii w sposób doskonały. Nie mówi się więcej o stanie doskonałości w Kościele. Jednak właściwym celem życia konsekrowanego, jak podkresla papież, jest „proroctwo”. Zakonnicy mają być prorokami, którzy przez wybór wartości ewangelicznych mają za zadanie „obudzić świat” (,svegliare il mondo”) na wartości królestwa Bożego. Tymi wartościami są z pewnością na pierwszym miejscu czystość, ubóstwo i posłuszeństwo, właściwe samemu Jezusowi z Nazaretu. Żyjąc tymi

„Obudźcie świat. Ewangelia - proroctwo - nadzieja”. Autor obecnego przyczynku był również zaproszony do zajęcia się tematem plenarnym Franciszkowej mistyki ,zbliżania się" do drugiego czlowieka (Franciszek, Adh. apost. Evangelii gaudium, 24.11.2013, nr 272; dalej: EG), prowadzącej do „mistyki spotkania" (www.youtube.com/watch?v=etQu3t5G0Oo\&feature=youtu. be\&t $=1 \mathrm{~h} 9 \mathrm{~m} 19 \mathrm{~s})$. 
wartościami przyszłego świata, zakonnicy budzą ludzki świat z uśpienia. Cały Kościół ma to usłyszeć. Zakonnicy mają być archegoi-tymi, którzy przygotowują drogę, krocząc nią jako pierwsi, patrząc na Jezusa, ,który nam w wierze przewodzi i ją wydoskonala” (Hbr 12, 2).

Cała historia bierze swój początek z pierwszego wywiadu, jakiego Franciszek udzielił „La Civiltà Cattolica”, odpowiadając między innymi na pytania o miejsce i rolę życia konsekrowanego w Kościele i świecie. Będąc sam zakonnikiem, odpowiedział tak:

Osoby zakonne są prorokami. Są tymi, którzy wybrali podążanie za Jezusem, naśladując Jego życie w posłuszeństwie Ojcu, w ubóstwie, w życiu wspólnotowym i w czystości. W tym sensie śluby zakonne nie mogą być parodią, w przeciwnym razie na przykład życie wspólnotowe staje się piekłem, a czystość stylem bycia starych panien. Ślub czystości powinien być ślubem płodności. W Kościele zakonnicy są wezwani szczególnie do bycia prorokami, którzy świadczą o tym, jak na tej ziemi Jezus żył, i którzy przepowiadają, jak królestwo Boże będzie wyglądać w swojej doskonałości. Zakonnik nigdy nie może zrezygnować z prorokowania. Nie oznacza to jednak trwania w opozycji do hierarchicznej części Kościoła, nawet jeśli funkcja profetyczna i struktura hierarchiczna nie idą w parze. Mówię o pewnej propozycji zawsze pozytywnej, która nie powinna napawać lękiem. Myślimy o tym, czego dokonali ci wszyscy wielcy święci mnisi, zakonnicy i zakonnice począwszy od św. Antoniego, opata. Bycie prorokiem czasami może oznaczać robić „ruido” (hałas, raban), nie wiem, jak to powiedzieć... Proroctwo wywołuje rumor, hałas, ktoś powie ,,bałagan”. Ale w rzeczywistości jego charyzmatem jest bycie zaczynem: proroctwo ogłasza ducha Ewangelii ${ }^{3}$.

Powyższe słowa odbiły się szerokim echem, zwłaszcza że otwarcie wskazały na możliwość ,,piekła na ziemi” także we wspólnotach życia zakonnego, wraz z absolutnie nieatrakcyjnym obrazem ,starych bigotek", tak żeńskich, jak i męskich. Trzy miesiące później, podczas

3 A. Spadaro, Intervista a Papa Francesco, „La Civiltà Cattolica” 164 (2013), s. 464-465 (t1. pol.: Serce wielkie i otwarte na Boga - całość wywiadu, http://www.deon.pl/religia/serwis-papieski/wywiady-franciszek/art,1,serce-wielkie-i-otwarte-na-boga.html). 
spotkania ojca świętego z przełożonymi generalnymi instytutów męskich w Rzymie 29 listopada 2013 roku, padło wiele ważkich stwierdzeń4. Wśród nich ważne dla nas zarysowanie istoty wymiaru profetycznego życia zakonnego i konsekrowanego.

Należy widzieć to w szerszym kontekście wypowiedzi papieża. Chodziło mu o wywołanie globalnej „rewolucji czułości” w odpowiedzi na globalizację obojętności na zło, krzywdę, wyobcowanie i wszelką biedę ludzką. Parę dni później Franciszek podpisywał adhortację Evangelii gaudium, w której potwierdził, że nie chodzi mu wyłącznie o wyrażenie poetyckie, lecz o sprawę, która bardzo leży mu na sercu już od rozpoczęcia pontyfikatu 5 .

Mówiąc do przełożonych generalnych, papież zachęcił osoby konsekrowane do podejmowania problemów z pieszczotliwością (accarezzare i problemi), rodzącą się z czułoścą, która może być postrzegana nawet jako „,zułość eucharystyczna... ”. Polskie tłumaczenie słynnego już tekstu poddano pewnej cenzurze. W naszym języku „pieszczota” wydaje się nie do przyjęcia w kontekście osób konsekrowanych; możemy co najwyżej mówić o „oswajaniu” problemów 6 . Zatem w kontekście rewolucji czułości padają ważne słowa odnośnie do profetyzmu zakonnego, w oparciu o wizję Benedykta XVI:

4 Por. A. Spadaro, „Svegliate il mondo”. Colloquio di Papa Francesco con i Superiori Generali, „La Civiltà Cattolica” 2014 z 19-23-29 sierpnia 2013, s. 3-17 (tł. pol.: Obudźcie świat, http://www.deon.pl/religia/serwis-papieski/dokumenty/przemowienia-papieskie/art,39,obudzcie-swiat.html).

5 Zob. EG 88. Franciszek, Homilia podczas Mszy św. na rozpoczęcie pontyfikatu (19.03.2013): ,Chciałbym prosić wszystkich tych, którzy zajmują odpowiedzialne stanowiska w dziedzinie gospodarczej, politycznej i społecznej, wszystkich mężczyzn i kobiety dobrej woli: bądźmy «opiekunami» stworzenia, Bożego planu wpisanego w naturę, opiekunami bliźniego, środowiska. [...] Nie powinniśmy bać się dobroci ani też czułości! Dodam tu jeszcze jedną uwagę: troszczenie się, opieka wymagają, by były przeżywane z czułością. W Ewangeliach św. Józef jawi się jako człowiek silny, odważny, pracowity, ale jest w nim wielka czułość, która nie jest cechą człowieka słabego - wręcz przeciwnie - oznacza siłę ducha i zdolność do zwracania uwagi na bliźniego, współczucia, prawdziwej otwartości na niego, zdolność do miłości. Nie powinniśmy bać się dobroci, czułości!”.

6 Przypis 11 do tekstu Colloquio: „W oryginale jest pieszczac, glaszczac konflikty, wyrażenie nieprzetłumaczalne na język polski, chodzi w każdym razie o postawę przyjaznego wręcz stawiania czoła konfliktom (przyp. tł.)". A. Spadaro, „Svegliate il mondo”. Colloquio di Papa Francesco con i Superiori Generali, art. cyt., s. 12-14. 
Kościół rośnie dzięki świadectwu, a nie przez prozelityzm. Świadectwo, które może naprawdę pociągnąć, jest związane z zachowaniami, które nie są codzienne: hojność, oderwanie, ofiara, zapomnienie o sobie, aby zająć się innymi. To jest świadectwo, „męczeństwo” życia zakonnego. I dla ludzi jest to ,sygnałem alarmowym”. Zakonnicy poprzez swoje życie mówią ludziom, [a ludzie reagują:] „Co się dzieje?”. Te osoby chcą nam coś powiedzieć! Te osoby wykraczają poza horyzont światowości!"’.

W ten właśnie sposób - kontynuował papież za Benedyktem XVI - życie zakonne musi wpłynąć na wzrost Kościoła drogą atrakcyjnego przyciągania.

Kościół zatem powinien być atrakcyjny. Obudźcie świat! Bądźcie świadkami odmiennego sposobu czynienia, działania, życia! Jest możliwe życie w odmienny sposób na tym świecie. Mówimy o spojrzeniu eschatologicznym, skarbach Królestwa wcielonych tutaj, na tej ziemi. Chodzi o pozostawienie wszystkiego, aby naśladować Pana. Nie, nie chcę powiedzieć: ,w sposób radykalny”. Radykalizm ewangeliczny nie jest tylko dla zakonników: jest wymagany od wszystkich. Ale zakonnicy idą za Panem w sposób szczególny, w sposób prorocki. Ja oczekuję od Was tego świadectwa. Osoby konsekrowane muszą być mężczyznami i kobietami zdolnymi do obudzenia świata ${ }^{8}$.

W trakcie rozmowy papież Franciszek powrócił raz jeszcze do tematu i do wyrażonych koncepcji, pogłębiając je w sposób zgodny z duchem czasu:

7 Benedykt XVI, Homilia podczas Mszy św. na inaugurację V Konferencji Generalnej Episkopatu Latynoamerykańskiego i Karaibów przy Sanktuarium w Aparecida (13 maja 2007). Papież Franciszek wiele razy powracal do tej koncepcji swojego poprzednika. Uczynił to w homilii u św. Marty 1 października 2013: „Gdy ludzie, narody widzą świadectwo pokory, cichości, łagodności, czują potrzebę, o której mówi prorok Zachariasz: «Chcemy pójść z wami!». Ludzie czują tę potrzebę świadectwa miłości, tej miłości pokornej, bez narzucania, bez samowystarczalności, pokornej, która adoruje i służy”. Cytat z Benedykta XVI odnajdziemy w przemówieniu papieża Franciszka wygłoszonym 4 października podczas wizyty w katedrze Św. Rufina w Asyżu, a także w adhortacji apostolskiej Evangelii gaudium, nr 14.

8 A. Spadaro, „Svegliate il mondo”. Colloquio di Papa Francesco con i Superiori Generali, art. cyt., s. 5. 
Musicie być naprawdę świadkami odmiennego sposobu działania i postępowania. Ale w życiu jest trudno, aby wszystko było jasne, precyzyjne, opisane w sposób konkretny. Życie jest złożone, składa się z łaski i grzechu. Jeżeli ktoś nie grzeszy, nie jest człowiekiem. Wszyscy popełniamy błędy i musimy rozpoznać naszą słabość. Zakonnik, który uznaje się słabym i grzesznikiem, nie zaprzecza świadectwu, do którego dania jest powołany, przeciwnie, wzmacnia je, i jest to z pożytkiem dla wszystkich. Tym, czego ja oczekuję, jest więc świadectwo. Pragnę od zakonników tego szczególnego świadectwa?

\section{Trudny charyzmat profetyzmu}

Wiemy z objawienia biblijnego, jak nieodzowne i zarazem trudne do ,,przetrawienia” jest proroctwo. Prorocy są Widzeniem, Głosem-Wyrocznią Pana w konkretnych sytuacjach historii narodu wybranego oraz Pieczęcią głoszonego orędzia i realizowanego dzieła, pieczęcią, która ostatecznie sprowadza się do świadectwa trwania aż do końca (męczeństwo).

Już sama obecność Nebiim, Proroków, jest łaską: kiedy wśród ludu jest prorok, oznacza to, że Pan (nadal) mówi, Pan jest (nadal) blisko, a to gwarantuje ocalenie i zbawienie. Ogromny niepokój zapada nad Izraelem, kiedy proroctwo wygaśnie: „Czyżby Pan zapomniał? A może już się nami zmęczył i wydał nas na pastwę skutków naszych rebelii?". Nie dziwi, kiedy po czterech wiekach nieznośnego milczenia, wśród narastających tragedii, kiedy zadanie rozświetlania historii przejęli apokaliptycy, w Izraelu nastąpiło tak wielkie poruszenie na wiadomość, że przy Jordanie pojawił się prorok mocny w słowie i postawie, wołający na pustyni: „Gotujcie drogę dla Pana” (por. Mt 3, 3; Mk 1, 2-4; Łk 3, 1-6). Według słów Jana Chrzciciela nadchodził już oczekiwany erchómenos, ten, który miał nadejść, by chrzcić „ogniem i Duchem Świętym” (Łk 3, 16). Wszyscy zmierzali ku miejscu, gdzie Jan nauczał, bo odrodziła się nadzieja: Pan nas nie zostawił! Pan dotrzyma obietnic! Pan zajmie się osobiście ,,robaczkiem Jakubem" (por. Iz 41, 14). 
Prorocy są potrzebni nawet w herezji i zdradzie, by fałszywie autoryzować, rozwiązania sprzeczne z wolą Boga. Tacy prosperują, choć są nieautentyczni. Prawdziwy prorok przeszkadza. Prędzej czy później będzie musiał umrzeć, a w dodatku, jak powiedział o sobie Prorok z Nazaretu, jest niemożliwe, by umarł poza Jerozolimą! (por. Łk 13, 33). Prorok jest nieodzowny, ale i bezbronny. Jego paradoks polega między innymi na tym, że w nieuniknionym zderzeniu z władzą ludu wybranego, lub nawet z całym ludem, chociaż jest Bogu najmilszy i nosi już w sobie to, co ogłasza, to właśnie on będzie musiał zginąć, nie lud.

Proroctwo to wizja, zanim nastanie słowo, jak to widzimy w historii powołania Jeremiasza, ,egzystencjalnej fotografii” Mesjasza. „I skierował Pan następujące słowa do mnie: "Co widzisz, Jeremiaszu?». Odrzekłem: «Widzę gałązkę drzewa czuwającego [migdałowego]» [...] «Dobrze widzisz, bo czuwam nad moim słowem, aby je spełnić»" (Jr 1, 11-12).

Kwiat drzewa migdałowego - nad czym zatrzymał się także papież Franciszek w jednej ze swoich homilii - ,jest pierwszym, który zakwita na wiosnę”. To oznacza, że „Pan jest tam, czuwający”, jest zawsze ,pierwszy jak migdałowiec, miłuje nas pierwszy”. I my także, zapewnił papież, ,zawsze będziemy mieli tę niespodziankę: kiedy zbliżamy się do Boga poprzez uczynki miłości, przez modlitwę, w komunii, w Słowie Bożym, przekonujemy się, że On tam jest jako pierwszy, czeka na nas i tak nas kocha”. I właśnie ,jak kwiat drzewa migdałowego - jest pierwszy"10.

Apogeum tego „,bycia pierwszym w miłości” następuje w pełni czasów, kiedy Wcielone Słowo przyjdzie do ludzi. Paweł Apostoł jest jednym z najwznioślejszych piewców tej nieoczekiwanej wieści: „Gdy ukazała się dobroć (chrestotes) i miłość (philanthropía) Zbawiciela, naszego Boga, do ludzi, nie ze względu na sprawiedliwe uczynki, jakie spełniliśmy, lecz z miłosierdzia swego zbawił nas przez obmycie odradzające i odnawiające w Duchu Świętym, którego wylał na nas obficie przez Jezusa Chrystusa, Zbawiciela naszego, abyśmy, usprawiedliwieni Jego łaską, stali się w nadziei dziedzicami życia wiecznego" (Tt 3, 4-7).

10 Papież Franciszek, Homilia u św. Marty, 8 stycznia 2015, www.osservatoreromano.va/pl/news/niech-pan-odmieni-serca-ludzi-okrutnych (dostęp 4.09.2015). 
Tłumacząc ten tekst, św. Hieronim miał nie lada trudność z oddaniem Bożej filantropii, lecz dokonał też fascynującego wyboru: oddał mianowicie w Wulgacie miłość Boga do ludzi jako humanitas ${ }^{11}$. Jest to najbardziej zaskakująca wizja Bożego planu miłości, co starała się uwypuklić teologia zachodnia: właśnie w Bogu mamy odnajdywać właściwą miarę naszego człowieczeństwa, tak piękną i fascynującą, że mowa o naszej „dywinizacji” powinna być ostrożniejsza. Założyciel zgromadzenia redemptorystów św. Alfons M. Liguori powiedział: „Rajem Boga jest - poniekąd - serce czlowieka” 12 . Proroctwo eschatologii w księdze Apokalipsy mówi istotnie nie tyle o naszym wstępowaniu ku Bogu, ile o Mieście Świętym, Oblubienicy i Małżonce Baranka, zstępującej „od Boga” ku odnowionej ziemi. „Bóg-z-nimi” to imię nowej ludzkości, poślubionej swojemu Panu (por. Ap 21, 3).

Kres historii zbawienia to Bóg ,wszystko-we-wszystkich” (por. 1 Kor 15, 28), w wydarzeniu Jezusa, ukrzyżowanego i zmartwychwstałego Mesjasza. Tak radykalna miłość kosztuje, a nade wszystko jest darem. Nie każdego zaś logika daru przekonuje: wprowadza ona przecież więź wzajemności i generuje współzależność. Dla wielu najstosowniejsza logika to należność otrzymywana na podstawie sprawiedliwości, wysługi bardziej, niż oparta na „bezpodstawnym” darze. Mesjasz musiał umrzeć między innymi przez swoje proroctwo zbawienia gratis, z czystej miłości, a nie dlatego że na to zasłużył.

\section{Nowe wyzwania dla profetyzmu konsekrowanego}

Jaka jest moc przyciaggania alternatywnej drogi życia, jaką podejmują osoby konsekrowane? Jak budzą one świat? Dzieje się to przez zaraźliwą siłę przyciągania, pochodzącą z ,przyszłości”. W tym sensie profetyzm zawsze był antycypacją świata, który dopiero nadejdzie. Jednakże, obok uobecniania przyszłości, profetyzm to także siła przekształcania teraźniejszości właśnie w kierunku tego, kim będziemy, „kiedy się to ujawni” (por. $1 \mathrm{~J} \mathrm{3,2).}$

11 W liturgii wschodniej Bóg Philanthropos pozostał jako podmiot niewyobrażalnej miłości do ludzi, Czełowiekolubiec w jęz. staro-cerkiewno-słowiańskim.

12 Alfonso Maria de Liguori: „ «Deliciae meae esse cum filiis hominum» (Prov. VII, 31). Il paradiso di Dio, per così dire, è il cuore dell'uomo", Opere Ascetiche, Roma 1933, t. I, s. 316. 
Wszystko rozgrywa się w każdej chwili obecnego życia Kościoła i świata. A wspólnota uczniów Chrystusa wezwana jest dziś do dwojakiego nawrócenia całego Kościoła, w którym nie mogą nie uczestniczyć osoby konsekrowane: jest to nawrócenie misyjne i zarazem nawrócenie pastoralne. By przyciągać profetycznie ludzi do nowości Jezusa, trzeba wyjść do ludzi, porzucając wygodę uwitego gniazda i pozwalając się niejako powalać brudem i zapachem poranionych grzechem ludzi.

Kościół wychodzący ku ludziom i zamieniający swoje struktury na terapeutyczną obecność (szpital polowy), zawsze miał w zakonnikach swoich najlepszych przedstawicieli. To jest stała chluba osób konsekrowanych, iż są zawsze na pierwszej linii. Obecnie jednak, zagrożeni malejącą liczbą powołań i zatrwożeni ryzykiem utraty świętych murów i tradycji, w niektórych częściach globu mogą być wystawieni na pokusę skupienia się na inwestowaniu energii nie w ewangelizację, lecz ocalanie samych siebie.

Jako jedyne lekarstwo na to powolne ,samobójstwo” papież Franciszek wskazuje nam mistykę wychodzenia naprzeciw drugiemu człowiekowi, mistykę spotkania. W Evangelii gaudium, nr 272, spotykamy jeden z najważniejszych tekstów Franciszka na ten temat. Także tu polskie tłumaczenie nas zawodzi: termin „mistyka” jest po prostu pominięty w tekście. Widocznie znowu polski tłumacz uznał, iż w Polsce nikt nie zrozumie (a może nawet nie zaakceptuje) tezy, iż mistyka może być przeżywana na zewnątrz klasztorów, w rozgardiaszu spotkania. A przecież już wcześniej papież wyraźnie zasygnalizował, że mistykę można utożsamić z samym życiem, i to w jego dość „chaotycznej” formie:

Dzisiaj, gdy sieci i narzędzia ludzkiej komunikacji osiągnęly niesłychany rozwój, stajemy przed wyzwaniem, by odkryć i przekazać „mistykę” życia razem, wymieszania się, spotkania, wzięcia za rękę [oryginał mówi o objęciu się lub wzięciu w ramiona], uczestnictwa w tej nieco chaotycznej masie, która może zamienić się w prawdziwe doświadczenie braterstwa, w solidną karawanę, w święte pielgrzymowanie. W ten sposób większe możliwości komunikacji przełożą się na większe możliwości spotkania i większą solidarność między wszystkimi. Gdybyśmy mogli iść tą drogą, byłoby to rzeczą tak dobrą, tak uzdrawiającą, tak wyzwalającą, tak bardzo rodzącą nadzieję! Dobrze wyjść poza siebie, by przyłączyć się do innych. Zamknięcie się w sobie oznacza kosztowanie gorzkiej trucizny osamotnienia, 
a ludzkość traci za każdym dokonywanym przez nas wyborem egoistycznym ${ }^{13}$.

Rozumiemy, że jeśli dla tłumacza jest problemem już zwyczajne uściskanie się, to tym bardziej będzie nim „mistyka” jako ,wychodzenie ku drugiemu” i - w efekcie - także „mistyka spotkania”:

Dlatego gdy zbliżamy się do innych [kiedy żyjemy mistyką zbliżania się do innych - ,cuando vivimos la mística de acercarnos a los demás y de buscar su bien"] z zamiarem szukania w nich dobra, przygotujmy się duchowo do przyjęcia najpiękniejszych darów Pana. Za każdym razem, gdy spotykamy się z drugim człowiekiem z miłością, znajdujemy się w sytuacji odkrycia czegoś nowego w odniesieniu do Boga. Za każdym razem, gdy otwieramy oczy, by rozpoznać drugiego, bardziej zostaje oświecona wiara, by rozpoznać Boga. Wynika z tego, że jeśli chcemy wzrastać w życiu duchowym, nie możemy przestać być misjonarzami. Zadanie ewangelizacji wzbogaca umysł i serce, otwiera przed nami duchowe horyzonty, czyni nas wrażliwymi, by rozpoznać działanie Ducha Świętego, pozwala nam wyjść z naszych ograniczonych schematów duchowych. Jednocześnie misjonarz w pełni oddany swojej pracy doświadcza przyjemności bycia źródłem, które rozlewa się i orzeźwia innych. Misjonarzem może być tylko ten, kto czuje się dobrze, kiedy dąży do dobra bliźniego, kto pragnie szczęścia innych. To otwarcie serca jest źródłem szczęścia, ponieważ „więcej szczęścia jest w dawaniu, aniżeli w braniu" (Dz 20, 35). Nie żyjemy lepiej, uciekając od innych, kryjąc się, odmawiając dzielenia się i zamykając się we własnej wygodzie. Jest to nic innego jak powolne samobójstwo ${ }^{14}$.

Słowa te są tak jasne, że nie wymagają dodatkowego komentarza. Ojciec święty Franciszek napisał je do całego Kościoła. Potwierdził je jednak szczególnie w Liście do osób konsekrowanych na rozpoczęcie roku im poświęconego, mówiąc w dwóch miejscach o ,,mistyce spotkania” i ,mistyce życia razem”:

Życie z pasją chwilą obecną oznacza stawanie się ,,ekspertami od wspólnoty”, ,,świadkami i współtwórcami tego "projektu wspólnoty», 
który jest u szczytu historii człowieka według Boga”. W społeczeństwie konfliktu, trudnego wspólistnienia różnych kultur, ucisku najsłabszych, nierówności powinniśmy, zgodnie z powołaniem, dawać konkretny wzór wspólnoty, która poprzez uznanie godności każdej osoby oraz dzielenie się darem, który wnosi każdy z nas, pozwala na życie w relacjach braterskich. Bądźcie więc kobietami i mężczyznami jedności, stawiajcie się odważnie tam, gdzie występują różnice i napięcia, i bądźcie wiarygodnym znakiem obecności Ducha, który wzbudza w sercach żarliwą miłość, aby wszyscy stanowili jedno (J 17, 21). Przeżywajcie mistykę spotkania, ,umiejętność słyszenia, słuchania innych osób. Umiejętność poszukiwania razem drogi, metody", pozwalając się oświecać relacją miłości, która istnieje między trzema Osobami Boskimi (1 J 4, 8), jako wzorem wszelkich relacji międzyludzkich ${ }^{15}$.

W drugiej części listu papież Franciszek stwierdza:

[...] niestrudzenie powtarzam, że krytyka, plotki, zazdrość, zawiść, antagonizmy są postawami, które nie mają prawa pojawiać się w naszych domach. A po przyjęciu tego założenia droga miłosierdzia, która się przed nami otwiera, jest niemal nieskończona, ponieważ trzeba dążyć do wzajemnej akceptacji i troski, praktykować wspólnotę dóbr materialnych i duchowych, braterskie upominanie, szacunek dla osób najsłabszych... Jest to , «mistyka» życia razem”, czyniąca z naszego życia „święte pielgrzymowanie”. Musimy się również zastanowić nad relacjami między ludźmi z różnych kultur, biorąc pod uwagę fakt, że nasze wspólnoty stają się coraz bardziej międzynarodowe. Jak można pozwolić każdemu, by wyraził siebie, został zaakceptowany ze swoimi szczególnymi darami, stał się w pełni współodpowiedzialny? ${ }^{16}$.

\section{Inne implikacje dzisiejszego profetyzmu zakonnego}

Ars moriendi - dzieła charyzmatów przemijają. Historyczne formy licznych charyzmatów w ogóle zniknęły, bo nie miał ich kto

15 Papież Franciszek, List do osób konsekrowanych Świadkowie radości, I, 2 [dalej ŚR].

16 ŚR II, 3. 
realizować. Ale i na odwrót, jeden wierny przedstawiciel czasem wystarczał, by charyzmat się odrodził w nowych warunkach.

Chercher la femme - kwestia równouprawnienia kobiety w życiu kościelnej wspólnoty. W życiu konsekrowanym mężczyźni nazbyt oddalili się od świata kobiet. Bóg stworzył człowieka jako mężczyznę i niewiastę, dlatego także w życiu konsekrowanym są oni sobie nawzajem potrzebni. Zbyt często traktowano się wzajemnie jako zagrożenie, stąd to historyczne oddalenie się od siebie. Dziś wspólpraca $\mathrm{w}$ ewangelizacji, zwłaszcza na różnorakich ,,peryferiach egzystencjalnych”, pokazała dobitnie, że można żyć mistyką spotkania także w tym wymiarze, przy nieodzownej dojrzałości osobowej i strukturalnej.

Nowe wino i nowe bukłaki - konsekrowanych jest na świecie prawie milion osób (około 950 tysięcy), ale też co roku odchodzi z zakonów 2-3 tys. osób. Odchodzą, bo - jak mówią - ,już nie są szczęsliwi w zakonie". Papież Franciszek nieustannie zachęca do lepszego rozeznania jakości powołań (discernere).

Adekwatna formacja - to ta, która odpowiada na ciągle nowe znaki czasu, a zarazem docenia to, że czlowiek to nieustanne wielkie „misterium”, ciągle zaskakujące w kolejnych pokoleniach. Nowością w formacji jest umiejętność uważnego słuchania formowanych i wprowadzania ich w życie bardziej bratersko-siostrzane, nacechowane autentyczną radością Ewangelii i życia wspólnotowego. Czasem, istotnie, osoby zakonne są samotne we wspólnocie. Radość przebywania z braćmi powstaje i utrzymuje się we wspólnocie będącej - antropologicznie i socjologicznie - prawdziwym domem.

Indywidualizm - wśród chorób współczesności - jest prawdziwą plagą, którą trzeba zwalczać, poczynając od siebie. Formacja zbyt sztucznie jest dzielona na początkową i permanentną, tymczasem ona winna być po prostu stała, nieustająca! W tym też sensie sami formatorzy muszę podlegać nieustannemu rozwojowi, inaczej bowiem będą formować młodszych na swój własny obraz i podobieństwo.

System władzy - kiedy jest sprawowany przez urząd i finanse - staje się bolesną karykaturą. Czasami, w praktyce życia, większe jest zaufanie do zasobów bankowych niż do Opatrzności Bożej, a przełożony staje się praktycznie ekonomem. Pokusa pomnażania środków materialnych jest jedną z najsubtelniejszych: ma zabezpieczać przyszłość, lecz nie w oparciu o „kapitał” Ducha. Dodatkowym elementem - śmiercionośnym w skutkach - są podziały na 
osoby bardziej i mniej ważne. Wspólnota umiera, bo nie ma w niej już Kościoła.

Nowa relacja między charyzmatami - pojawia się jako wymóg eklezjologii komunii, ale jest wprost unaocznieniem Ewangelii, która chce z wszystkich uczniów Chrystusa uczynić jedno na bazie wzajemnej miłości. Nie do przeoczenia jest też konieczność konkretnej współpracy, zwłaszcza tam, gdzie zadanie przekracza siły jednej rodziny zakonnej, by zajaśniała prawdziwa ewangeliczna globalizacja solidarności wszystkich odkupionych.

\section{Obudzić świat, poczynając od samych siebie}

Odrzuciwszy z papieżem Franciszkiem pochodzącą z romantyzmu, zawężoną wizję proroka jako jasnowidza, który jedynie przepowiada rzeczy tajemnicze i przyszłe, osoby życia konsekrowanego wracają skuteczniej do własnej tożsamości i misji, które są im dane i zadane, do realizacji w ,tu i teraz” ludzkiej rodziny.

Cóż takiego mieści się w naczyniach glinianych ich powołania? Ograniczoność i nieadekwatność ludzka, z której powołuje Pan, jako krucha glina wypalona w ogniu prób, zawiera i nosi w sobie przeogromny skarb utożsamienia z Jezusem, pierwszym konsekrowanym. Postępując na drodze rad ewangelicznych, ze względu na doznane miłosierdzie (,miserando atque eligendo”), jako pierwsi mają szansę rozpalić w tym szczególnym roku łaski pierwotny ogień powołania i ożywić otrzymany charyzmat, aby pozwolić nowości Ducha ujawnić się w rozmaitych chaosach obecnego świata. Zastrzegając się na nowo, że nie uważają się za lepszych od innych, konsekrowani mają kolejną okazję, aby ponownie ,zdumieć się” wielkością otrzymanego daru.

Zadziwienie i zdumienie budzą się spontanicznie, kiedy zaczyna się rzeczywiście na serio wierzyć w stwierdzenia Magisterium Kościoła, według którego konsekrowani są ,,żywą pamiątką” życia Jezusa, kiedy - powodowani doskonałą miłością rad ewangelicznych (perfecta caritas) - postępują za Chrystusem posłusznym, czystym i ubogim z coraz większym ,naciskiem” (pressius) osobistej z Nim więzi.

Podobny stupor - zadziwienie - musi budzić w kroczących tą drogą magna charta ich konsekracji, adhortacja Vita consecrata, według której stają się razem wyznaniem Trójcy Przenajświętszej, znakiem 
powszechnego braterstwa i posługą wzajemnej miłości (confessio Trinitatis, signum fraternitatis oraz servitium caritatis). Są to autentyczne „zwierciadła Nieba”, w których nie tylko można, lecz trzeba się przeglądać, aby dostrzec, jak realizuje się Boża ,wyobraźnia miłosierdzia" wobec świata poprzez obecność i posługę życia zakonnego.

Wszystko to jednak w pogłębiającej się świadomości prorockiej „alternatywy”: konsekrowani przychodzą z przyszłości, ukazując, jaka będzie ludzkość, kiedy odkupienie dokona się w pełni. Przyszłość ta zasadza się na przeszłości, jednak nie tylko tej materialnie historycznej, choć wpisują się w nią konkretne początki charyzmatu kolejnych założycieli. Konsekrowani - jak wszyscy wierzący - pochodzą z przeszłości w sensie eksplozji Nowego Świata, która nastąpiła w zmartwychwstaniu Jezusa, tak że ich , bycie w Nim” musi nosić wyraźne znaki ,nowego stworzenia”. Żaden postęp czysto ludzki, jak postuluje choćby dzisiejszy transhumanizm, nigdy nie zdoła wytłumaczyć nowości i uprzedzającej wartości ,,paradygmatu" wobec wszelkiego progresu techniki. Zmartwychwstały Jezus obejmuje cały wszechświat i to dlatego „w Nim żyjemy, poruszamy się i jesteśmy". Tak dalece posunięta bliskość Pana pozostanie na zawsze wprost niewyobrażalna, ale trzeba umieć ją odczytywać i odnajdywać się w niej, będąc jednocześnie osobistym znakiem, wspólnotowym dowodem oraz środowiskiem.

Siła atrakcji rodzi się tutaj, w centrum wszystkiego, w Jezusie ukrzyżowanym i zmartwychwstałym, tutaj też rodzi się nowa mistyka, bez której charyzmaty tracą swoją moc i zanikają.

Chodzi najpierw o „kontemplatywne” spotkanie spojrzeń. Absolutnie pierwotne jest poddanie się spojrzeniu Jezusa: to On nas widzi, On nas kontempluje i... odsyła do swoich ran w ludzkości. Wielką - moim zdaniem - nowością teologiczną wskazań papieża Franciszka jest to, że podobnie jak w chlebie eucharystycznym obecny jest prawdziwie i realnie Jezus w akcie swojego oddania się Ojcu za nas na krzyżu, jak również w akcie swojego zmartwychwstania dla nas, tak też obecne są święte rany Pana w ranach ludzkości. Adoracja Sanctissimum, adoracja krzyża świętego, prowadzi nas do swoistej adoracji ran Jezusa rzeczywiście obecnych w zranieniach braci i sióstr, którym trzeba bez zwłoki przynieść ulgę i uzdrowienie.

Tutaj wychodzi prawda o konsekracji zakonnej: eksperci od komunii, żywa egzegeza Słowa Bożego, minoritas - bracia i siostry „,mniejsi” od wszystkich innych, bo umywający im stopy, jak to czynił Pan w wieczerniku. 


\section{Dom odkupionych relacji, które leczą świat}

Nawrócenia są obecnie nawet trzy: misyjne, pastoralne i ekologiczne. Wszystko bowiem jest powiązane i wszystko wszystkiemu ma służyć.

Konsekrowani obudzą więc świat pełnym szacunkiem dla osoby ludzkiej, wychodząc jej na spotkanie, aby pomóc i odnaleźć się w pełni wspólnoty Boga i ludzkości. Świat osób zakonnych obudzi się, widząc na własne oczy długo oczekiwane przekształcenie ,życia we wspólnocie” we „wspólnotę życia”.

Sam Pan rozraduje się ze swoich dziel, kiedy osoby konsekrowane w Chrystusie ujawnią się jako fontanny radości i światła dla świata. Trójca Święta „odbije się” przecież wśród stworzeń, a każdy człowiek będzie miał szansę doznać „bliskości Jezusa” - jedynej bliskości, która budzi świat do życia - w sobie, w innych i pośród innych.

W tym sensie najbardziej oczekiwany profetyzm życia zakonnego powróci do swojej prostoty: „Szukajcie wpierw Królestwa Bożego i jego sprawiedliwości" (por. Mt 6, 31-33). Królestwo to bowiem "wśród was jest" (por. Łk 17, 20-21), wpisane w wasze relacje, które tak jak wszystkie inne relacje w stworzeniu noszą na sobie sład i jakość jedności Trójcy:

Osoby Boskie są relacjami samoistnymi, a świat stworzony na wzór Boga jest siecią relacji. Stworzenia skierowane są ku Bogu, a cechą wszystkich istot żywych jest dążenie do innego stworzenia tak, że we wszechświecie można znaleźć niezliczone, trwałe relacje, które wzajemnie tajemniczo się przeplatają. Zachęca to nas nie tylko do podziwiania wielu powiązań istniejących między stworzenia$\mathrm{mi}$, ale prowadzi także do odkrycia klucza naszej samorealizacji. Byt ludzki bowiem tym bardziej się rozwija, tym bardziej dojrzewa i tym bardziej się uświęca, im bardziej wchodzi w relacje, przekraczając siebie, aby żyć w komunii z Bogiem, z innymi i ze wszystkimi stworzeniami. W ten sposób przyjmuje w swoim życiu ową dynamikę trynitarną, jaką Bóg w nim odcisnął od początku jego istnienia. Wszystko jest połączone, a to nas zachęca do dojrzewania w duchowości globalnej solidarności, która emanuje z tajemnicy Trójcy Świętej ${ }^{17}$.

17 Papież Franciszek, Enc. Laudato si, nr 240. 
Profetyzm osób konsekrowanych polega właśnie na tym: nie czekając na lepsze rozwiązania, najlepszej nawet, ludzkiej techniki, pokazać światu „na sobie”, w „tu i teraz” Kościoła, że nowe stworzenie rzeczywiście nastąpiło i niestrudzenie buduje dla odkupionej ludzkości ten dom, za którym tęskni każde ludzkie serce.

Andrzej Wodka CSSR, Proroctwo życia osób konsekrowanych: „,być domem” odkupionych relacji ewangelicznych, [w:] Życie konsekrowane znakiem wiarygodności Kościoła, red. ks. Andrzej Dudek, ks. Robert Kantor, Kraków 2016, s. 88-104 (Lumen Gentium, 2).

DOI: http://dx.doi.org/10.15633/9788374385725.07 